ISSN 0258-7122

Bangladesh J. Agril. Res. 36(1) : 103-109, March 2011

\title{
INVESTIGATION INTO EFFECT OF CRUDE MIXTURE OF Abrus precatorius SEED ON HYPOTHALAMOPITUITARY GONADAL AXIS AND DEVELOPMENT OF ANTIFERTILITY IN MALE RATS
}

\author{
S. TALUKDER ${ }^{1}$, M. A. HOSSAIN ${ }^{2}$, S. SARKER ${ }^{3}$ \\ AND M. A. H. KHAN ${ }^{4}$
}

\begin{abstract}
To evaluate the antifertility effect of crude mixture of A. precatorius seeds at the dose level of $50 \mathrm{mg} / \mathrm{kg}$ body weight in adult male rats, after oral administration to male rats for 40 days, the rats were sacrificed and hormonal profiles, serum biochemistry, sperm count and histological changes were recorded. A sharp decrease in the serum levels of testosterone $(0.70 \pm 0.17 \mathrm{ng} / \mathrm{ml})$, FSH $(0.70 \pm$ $0.22 \mathrm{lU} / \mathrm{L})$, and $\mathrm{LH}(0.87 \pm 0.35 \mathrm{IU} / \mathrm{L})$ was detected compared to control (FSH, $\mathrm{LH}$ and testosterone levels $0.93 \pm 0.15 \mathrm{ng} / \mathrm{ml}, 0.76 \pm 0.28 \mathrm{IU} / \mathrm{L}, 1.44 \pm .011$ IU/L, respectively). A significant reduction of epididymal sperm count (2.34 million/mL) was noted in treated rats as compared to control group (7.87 million/mL). Histology of testes showed marked atrophy of the testes, which was characterized by disruption of the seminiferous epithelium and atrophy of the Leydig cells. Crude mixture of A. precatorius seed has a negative impact on male reproductive functions. It might be suggested that crude mixture of $A$. precatorius seeds might have antifertility property for male rats.
\end{abstract}

Keywords: Abrus precatorius, antifertility, male rat, testosterone.

\section{Introduction}

The world population was 2.55 billion in 1950, 7.7 billion in April 2009 and is still increasing at the rate of $1.15 \%$ annually (Carl and Mary, 2009). Bangladesh, the eighth most populous nation in the world is also one of the poorest with per capita income of less than US \$ 1500 per year. In the face of increasing population, especially in developing countries like Bangladesh, a continuing need is felt for male oral contraception. While chemical methods for fertility regulation in the female are available, the 'male pill' regimens are still toxic and inconvenient.

Fertility regulation with plant preparations had been reported in ancient literature of indigenous systems of medicine. The seeds of $A$. precatorius have various medicinal uses. It is used in Srilanka by Ayurvedic practitioners as an

${ }^{1}$ Department of Biochemistry, Faculty of Agriculture, Bangladesh Agricultural University (BAU), Mymensingh 2202, ${ }^{2}$ Professor, Department of Biochemistry, Faculty of Agriculture, BAU, Mymensingh-2202, ${ }^{3}$ Lecturer (Pathology), Department of Animal Husbandry and Veterinary Science, Faculty of Agriculture, University of Rajshahi, Rajshahi 6205, ${ }^{4}$ Professor, Department of Pathology, Faculty of Veterinary Medicine, BAU, Mymensingh 2202, Bangladesh. 
oral contraceptive (Ratnasooriya et al., 1991). Various African tribes use mixtured seeds as oral contraceptive (Watt and Breyer-brandwijk, 1962). The seeds were used to treat diabetes (Monago and Akhidue, 2003; Monago and Alumanah, 2005) and chronic nephritis. Very recently, an experimental evaluation of A. precatorius seeds for female antifertility activity was performed (Hannan et al., 2006). The present study was an effort to evaluate the effect of crude mixture of $A$. precatorius seeds on male fertility to try for male contraception. The study was designed to investigate the impacts of crude mixture of A. precatorius seeds on reproductive parameters in terms of hormonal profiles (LH, FSH, and testosterone), arrested spermatogenesis and histology of male reproductive organs.

\section{Materials and Method}

\section{Plant material}

The seeds of A. precatorius were purchased from the Ayurvedic Medicine Stores. The seeds were pulverized and suspended with distilled water.

\section{Experimental animals}

Six adult males and six adult females mixed albino rats (Long Evan's strain- 2.5 months old) weighing approximately $150 \mathrm{~g}$ were obtained from International Center for Diarrhoeal Disease Research, Bangladesh (ICDDR,B), Mohakhali, Dhaka. All the experimental rats were housed in plastic cages and kept in the Laboratory Animal House, Department of Biochemistry, Bangladesh Agricultural University, Mymensingh. The rats were acclimatized under standard laboratory conditions (12 h light: $12 \mathrm{~h}$ dark) for a period of 2 weeks before the commencement of the study. The male rats were certified fertile by isolated mating technique, while the female rats were certified to have regular estrous cycles by vaginal smears, before inclusion in this study. Food pellets (provided by ICDDR,B), and water were supplied adlibitum.

\section{Experimental design}

Six male albino rats of proven fertility were divided into equal two groups. Group I served as untreated control. Rats in Group II were treated daily with 50 $\mathrm{mg} / \mathrm{kg}$ body weight of A. precatorius seeds mixture for 40 days. Water suspended crude mixture of A. precatorius seeds were administered orally to the male rats with the help of micropipette. The experiment was conducted during March-June 2008.

\section{Tissue and blood sample collection}

By the end of each treatment, all rats were exposed to mild ether anesthesia. Then blood was collected using a syringe and needle directly by cardiac puncture and allowed to clot in the $15 \mathrm{ml}$ centrifuge tube. Reproductive organs, such as testes, 
epididymis, prostate, and seminal vesicle gland from the sacrificed rats were kept in $10 \%$ neutral buffered formalin for histologic study of the treatment response.

\section{Serum biochemistry}

Serum aspartate aminotransferase (AST), Alanine aminotransferase (ALT) and Serum creatinine were measured using commercial kits from Biosystem, Spain. The kits exploited the underlying principle of determination outlined by Reitman and Frankel (1957) for SGPT and SGOT activity and by Tietz et al. (1986) for creatinine activity.

\section{Hormonal assays}

Plasma follicle stimulating hormone (FSH), Luteinizing hormone (LH), and Testosterone hormone concentration were measured by radioimmunoassay using commercial kits from Beijing Atom, Hightech Co. Ltd., Beijing. The assay methods depend on the competition for sites on hormone (FSH/LH/testoserone)specific antibody between ${ }^{125}$ I-labeled hormone and hormone in the patient sample or the standard. The proportion ${ }^{125}$ I-labeled hormone bound to the antibody is inversely related to the amount of hormone in the unknown sample. After incubation for a fixed time, separation of bound from free is achieved by adding the precipitating solutions. The radioactivity of the precipitate is then counted. After drawing a standard curve, the sample serum hormonal concentration can be read off a standard curve.

\section{Histological evaluation of visceral organs}

For the histopathological study, the representing tissues from epididymis, prostate and seminal vesicle were collected in $10 \%$ neutral buffered formalin, dehydrated in descending grade of alcohol, cleared in chloroform and impregnated in paraffin. Then 5-6 $\mu \mathrm{m}$ sections were collected into the grease free slide, deparaffinized in xylene and stained with H \& E (Luna, 1968).

\section{Sperm collection and analysis}

To determine sperm, $100 \mathrm{mg}$ of cauda epididymis was minced in 2m1 RPMI1640 containing $10 \%$ calf serum and incubated at $37^{\circ} \mathrm{C}$ temperature. After 4 hours, the sample was mixed by pipetting and allowed to stand for larger fragments to settle down. The supernatant was collected, washed twice in RPMI1640 and spinned down at 1500rpm for 5 minutes. The supernatant was removed, diluted the sediment in $1 \mathrm{ml}$ RPMI-1640 and count the number of motile spermatozoa using trypan blue dye exclusion technique (Khan et al., 2008; Prasad et al., 1972). 


\section{Statistical analysis}

For each parameter, a minimum of five replicates were used and the results were expressed as Mean \pm Standard Error (S.E.). All the data were analyzed under one way analysis of variance with least significant differences at $\mathrm{p}<0.01$.

\section{Results and Discussion}

\section{Effect on serum levels of FSH, LH, testosterone}

There was a significant decrease $(\mathrm{p}<0.01)$ in serum levels of FSH, LH, and testosterone of the male rats treated with crude mixture of $A$. precatorius seeds when compared with the control group (Table 1). Reduction in serum testosterone level might be accounted for insufficient secretion of androgen resulted from inadequate sperm production and maturation process in both testicles and epididymis. It might be a probable cause for testicular and epididymal dysfunction as a result of androgen insufficiency. Hence, sperm production and maturation process in both organs were affected in treated male rats. Studies involving hypophysectomy, castration, and androgen replacement therapy revealed that androgens are essential for physiological maturation and survival of the spermatozoa in the epididymis (Kastner and Apfelbach, 1987).

Table 1. Serum FSH and LH (IU/L) and Testosterone $(\mathrm{mg} / \mathrm{ml})$ level in experimental male rats treated with crude mixture of $A$. precatorius seeds.

\begin{tabular}{|c|c|c|c|c|}
\hline Groups & Dose & $\begin{array}{l}\text { Serum FSH } \\
\text { level (IU/L) }\end{array}$ & $\begin{array}{c}\text { Serum LH } \\
\text { level (IU/L) }\end{array}$ & $\begin{array}{c}\text { Serum } \\
\text { testosterone } \\
\text { level }(\mathrm{ng} / \mathrm{mL})\end{array}$ \\
\hline Group I & Control & $0.93 \pm 0.15$ & $0.76 \pm 0.28$ & $1.44 \pm .011$ \\
\hline Group II & $\begin{array}{c}50 \mathrm{mg} / \mathrm{kg} \text { body } \\
\text { weight }\end{array}$ & $0.70 \pm 0.20$ & $0.67 \pm 0.35$ & $0.70 \pm 0.17$ \\
\hline
\end{tabular}

\section{Pathophysiological effect on body tissues}

Histoarchitectural investigation of the testes and epididymis of male rat treated with crude seeds mixture revealed degeneration of germinal epithelium. There was a lack of primary and secondary spermatocytes and sperms in the lumen of convoluted seminiferous tubules. The concentration of seminiferous epithelium was greatly reduced, only few tubules containing dead or degenerating tail piece of spermatozoa and most of the tubules lacking spermatids (Fig. 1). Leydig cells or interstitial cells were present around the small capillaries in the intertubular space but the number and size were greatly reduced. There was cytoplasmic atrophy of the interstitial cells and darkening of the nuclei (Fig. 1). The epididymis in the same treated rats showed many empty tubules containing degenerated spermatozoa or lacking of spermatozoa. There was atrophy of the cytoplasmic component of the lining epithelial cells and the cells were turned 
down stratified columner epithelium. Infiltration of macrophages and deposition of cellular debris and macrophage in the lumen of the tubules of epididymis were also observed (Fig. 1).

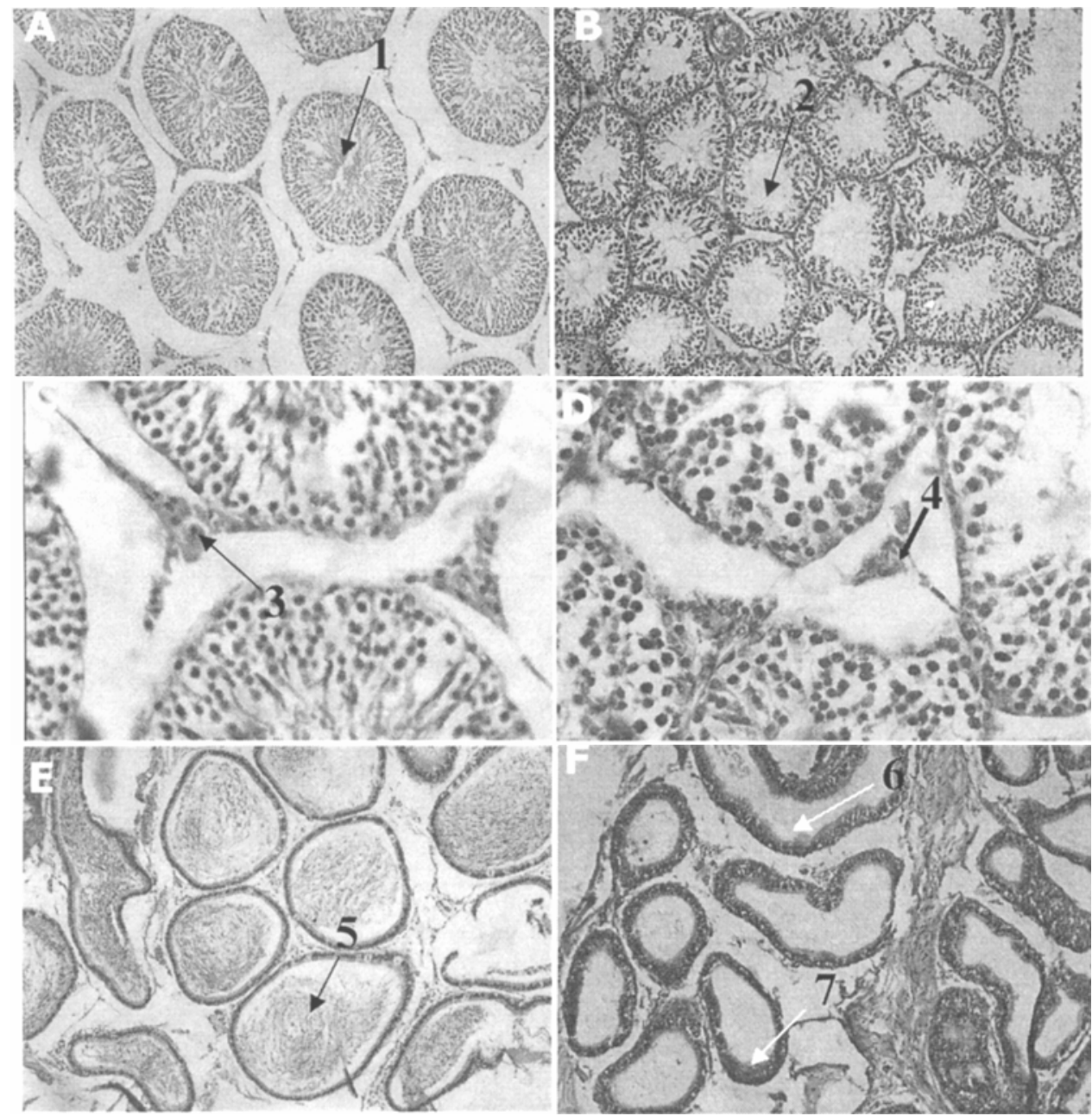

Fig. 1. Histology of rat testis (A, control) showing convoluted seminiferous tubules containing regularly organized germ cells and spermatids in the lumen (1); section of treated testis (B, treated with crude seeds mixture) showed seminiferous tubules lacking sufficient spermatozoa and disorganized germinal epithelium; section of testis (C, control), showing normal Leydig cell in inter tubular space (3); in contrast to treatment with crude seeds mixture at $50 \mathrm{mg} / \mathrm{kg}$ body weight (D), showing cytoplasmic atrophy of Leydig cell \& darker nuclei (4); section of a tail of epididymis (E, control) showing tubules full of spermatozoa (5), section of treated testis (F, treated with crude seeds mixture) showing tubules lacking spermatozoa (6), lining epithelium turned to stratified columner epithelium (7). 
The degeneration of the germ cells at $50 \mathrm{mg} / \mathrm{kg}$ body weight treatment was in accordance with Waller et al. (1983), who reported a similar result in gossypoltreated hamsters. This disruptive effect might have direct or indirect effect on androgen production of the testes. Since the tubules require a high concentration of androgen and the histological changes observed in the tubules may be due to shortage of testicular androgen production. The presence of vacuoles in the epididymis may be due to hormonal imbalance and disrupted spermatogenesis in testes.

Table 2. ALT, AST and creatinine level (IU/L) in experimental male rats treated with crude mixture of $A$. precatorius seeds.

\begin{tabular}{c|c|c|c}
\hline Groups & $\begin{array}{c}\text { ALT activity } \\
\text { (IU/L) }\end{array}$ & $\begin{array}{c}\text { AST activity } \\
(\mathrm{IU} / \mathrm{L})\end{array}$ & $\begin{array}{c}\text { Serum creatinine } \\
\text { activity (IU/L) }\end{array}$ \\
\hline Group I (Control) & $57.0 \pm 5.57$ & $261.66 \pm 34.42$ & $1.35 \pm 0.6$ \\
Group II & $48.66 \pm 4.04$ & $228.33 \pm 29.37$ & $1.33 \pm 0.86$ \\
\hline
\end{tabular}

\section{Effect on sperm dynamics}

Crude mixture of Abrus precatorius seeds showed lower sperm count (2.34 million/mL) than control group $(7.87$ million/mL) and are presented in Table 3. This inhibition of spermatogenesis as seen in this study might be due to unavailability of $\mathrm{FSH}, \mathrm{LH}$, and testosterone alone or in combination, since the level of these serum hormones was reduced. A decrease in sperm count was also documented by treatment of steroidal fraction of seeds of A. precatorius in male rats (Sinha and Mathur, 1990).

Table 3. Sperm count in experimental male rats treated with crude mixture of Abrus precatorius seeds.

\begin{tabular}{c|cc}
\hline Groups & Dose & Sperm count (million $/ \mathrm{mL})$ \\
\hline Group I & Control & $7.87 \pm 0.24$ \\
Group II & $50 \mathrm{mg} / \mathrm{kg}$ body weight & $2.34 \pm 0.26$ \\
\hline
\end{tabular}

\section{Effects on serum ALT, AST, and creatinine levels}

Effects of crude mixture of A. precatorius seeds treatments on AST, ALT, and creatinine activities have been investigated and are presented in Table 2. The results showed that $A$. precatorius seeds mixture had no deleterious effect on the liver, kidney, and pancreas. The crude mixture did not alter ALT, AST, and serum creatinine level which further indicated that there was no toxic effect of A. precatorius on liver and kidney function.

The results supported a possibility of hypothalamic pituitary site of action of crude mixture of A. precatorius seeds. This finding might be associated with subnormal levels of gonadotrophins (LH, FSH) secretion that might have reduced 
the number of sufficient sperms in the lumen of convoluted seminiferous tubules. Moreover, reduced testosterone is a probable cause for testicular and epididymal function as a result of androgen deprived effect. Hence, sperm production and maturation process in both respective organs were affected by the mixture feeding. This study showed that crude seeds mixture of A. precatorius induced functional antifertility without toxic symptoms. Further studies including in vivo fertility are needed and to isolate the active principles to evaluate further the active ingredient of antifertility potentials.

\section{References}

Carl, H. and M. K. Mary. 2009. World Population Data Sheet (Washington, DC: Population Reference Bureau, 2009)

Hannan, A. M., M. A. Hossain, M. T. Islam and E. H. Chowdhury. 2006. Contraceptive effects of Abrus precatorius seed on female rats. J. Bangladesh Soc. Agric. Sci. Technol. 3(3\&4): 185-188.

Kastner, D. and R. Apfelbach. 1987. Effects of cyproterone acetate on mating behavior, testicular morphology, testosterone level and body temperature in male ferrets in comparison with normal and castrated males. Hor. Res: 25: 178-184.

Khan, M. A. H., H. Ogita, V. A. Fero, K. Kumasawa, T. Tsutsui and Kimura. 2008. Immunisation with a piasmid DNA vaccine encoding gonadotrophin releasing hormone (GnRH-I) and T-helper epitopes in saline induces an anti-Gnrh-I antibody response and suppresses rodent fertility. Vaccine 26 (10): 1365-1374.

Luna, L. G. 1968. Manual of histologic staining methods of the Armed Forces Institute of Pathology. 3rd edn. McGraw Hill Book Co., New York, USA, 96-99. Monago, C. C. and V. Akhidue. 2003. Antidiabetic effect of crude glycoside of A. precatorius in alloxan diabetic rabbits. Global J. Pure Applied Sci. 9(1): 35-38.

Monago, C. C. and E. 0. Alumanah. 2005. Antidiabetic effect of chloroform-methanol extract of A. precatorius Linn seed in alloxan diabetic rabbits. J. Applied Sci. Environ. Manage 9(1): 85-88.

Prasad, M. R., N. J. Chinoy and K. M. Kadam. 1972. Changes in succinic dehydrogenase levels in the rat epididymis under normal and altered physiologic conditions. Fertil. Steril. 23: 186-190.

Reitman, S. and S. Frankel. 1957. Transaminases colorimetric determination of GOT and GPT activity. Am. J. Clin. Path. 28: 56.

Sinha, S. and R. S. Mathur. 1990. Post-testicular antifertility effects of Abrus precatorius seed extract in albino rats. Int. J. Exp Biol. 28: 752-756.

Tietz, N. W. 1986. Textbook of Clinical Chemistry, W. B. Saunders, 1271P.

Waller, D. P., L. J. D. Zaneveld and N. R. Farnsworth. 1983. Effect of (+) gossypol on fertility in male hamsters. J. Androl. 4: 276-279.

Watt, J. M. and M. G. Breyer-Brandwijk. 1962. The Medicinal and Poisonous Plants of Southern and Eastern Africa. Second Edition, Livingstone, London. 